\title{
LTBP2 Gene
}

National Cancer Institute

\section{Source}

National Cancer Institute. LTBP2 Gene. NCI Thesaurus. Code C24561.

This gene is involved in extracellular matrix interactions and in cellular adhesion. 